1.はじめに

海洋エネルギーは無償で得られる貴重なエネルギー資源ではあるが、これを有効に利用する技術には、なお未 解決の問題が存在する。筆者らは落差を利用する揚水装置を研究し、豆きにこれを有明海の潮汐発電に適用する ことを提案したが、今回はての装置を簡易化して、大量の流量を処理し得る方法により、その有効性を検討する。 本間䝅也氏によると、地球上の潮汐エネルギーの総量は、約 $3 \times 10^{9} \mathrm{~kW}$ といら膨大な量であるが、利用できる 分はわずかに $1 \%$ ぐらいに過ぎないと言われる。乙れは潮汐発電に必要な適地が少ないてとが原因であるが、恵 まれた立地条件を有する国にとっては、極めて重要なエネルギー源になり得るものである。特にアメリカ・カナ ダ国境のフォンデー湾、アルゼンチンのサンホセなどでは、その開発が待たれていると報告された。また、アジ アでは、中国・朝鮮などにも有望な地点が存在するので、わが国にとっても身近かな問題である。

さて潮汐の周期は、約 12 時間 25 分で、1 日にほぼ 2 回生ずるので、とのエネルギーを位置エネルギーに変換し てダムに貯水する。次にこれを発電に利用すると、ダムの水位と海面との落差は、水量の放出とともに小さくな り、発電量は減少または停止するので、その変動性の大きいてとが欠点になっている。もちろん各種の眝水方式 や、揚水併用方式なども考えられているが、その他に上記の欠点を補らべき発電技術を確立しなければ、エネル ギーの質の面で、一般水力のような評価は得られないと思う。筆者らの研究は、小規模のものではあるが、この 問題について、1つの提案をする。

\title{
2. 落差変換の方法
}

落差の変換には揚水装置を用いる。基本構造については前回報告したが、その概要は低落差のエネルギーを空 気エネルギーに変換する作動水室と、揚水室を段状に配列した階段状水室により構成される。空気エネルギーは気 圧回路でコントロールして、作動水室から階段状水室に供給されるので、下方水室から上方水室へ順次揚水するて とができる。図一(1)に示すものは実験用に製作した A 型である。作動水室は $\mathrm{A}(+)$ 圧、 $\mathrm{B}($ 压の 2 箇で、夫々ドック の中に固定してある。階段状水室は 5 段で揚水回路により連結される。ての両者を落差地点に設置し、先ずドック

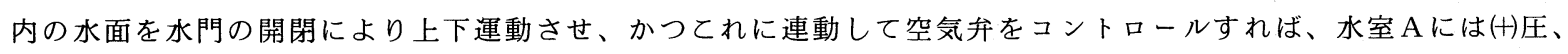
$\mathrm{B}$ には(圧を発生させることができる。階段状水室は相隣る 2 箇を以て 1 ユニットとするときは、上方水室には (十圧、下方水室には(十)圧を作用させることにより、吸上げポンプと押上げポンプを同時に適用したことになる。

最上段に達した水は(十)圧によって揚水池 に送水し、同時に最下段の水室は(十圧によ って H.W.L.より取水する。作動水室のエ ネルギーを有効水頭で表わすと、初落差 $\mathrm{H}_{1}$ から終落差 $\mathrm{H}$ までとなり、下限 $\mathrm{H}$ は揚程 $\mathrm{H}^{\prime}$ との関係から決める。

揚水装置の形態は、目的によりいろいろ 変えることができるので、A,B,C,D の 4 種 を考えたが、A，B は高所にエネルギーを貯 蔵する場合に適用される。乙れに対し、C, $\mathrm{D}$ は小揚程の場合に大量の流量を処理する ことができるので、潮汐発電に適用される。

(1) C 型

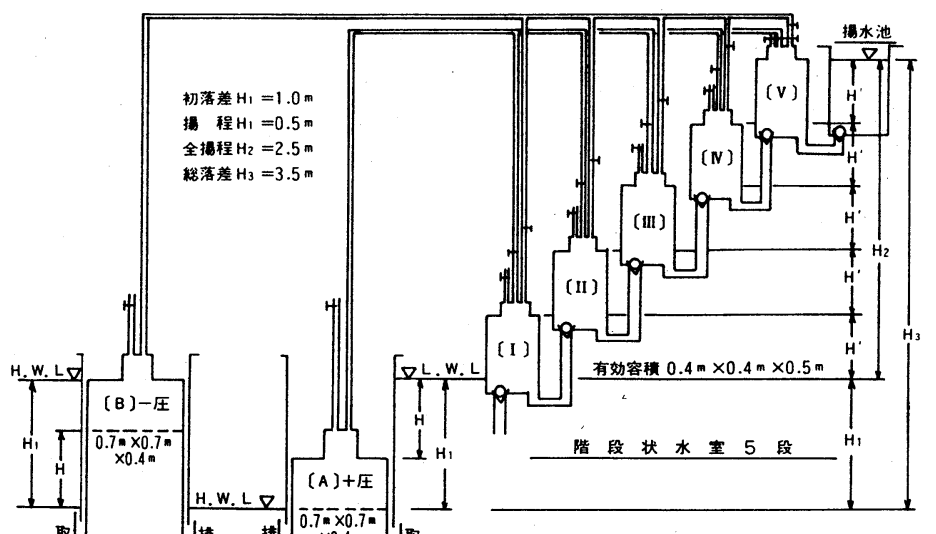

図-(1)

この装置は図ー-(2)に示すように、基本型である A 型の階段状水室を1段とし、その下に揚水室をつけたものである。

（第 1 行程） 作動水室 $\mathrm{B}(-)$ 圧は、最初取水水門を開き、満水にして水門を閉じる。次に排水水門を開いてL.W. L.に排水するとけ圧が生ずる。

揚水室は、最初取水水門を開き満水にし、次に作 動水室から(压を作用させると、水位が上昇して揚 程 $\mathrm{H}^{\prime}$ の高さにある階段状水室が満水する。

（第 2 行程） 作動水室 $\mathrm{A}($ ()圧は、最初は空虚な状 態にしておき、次に取水水門を開くと(十)圧が生ずる。

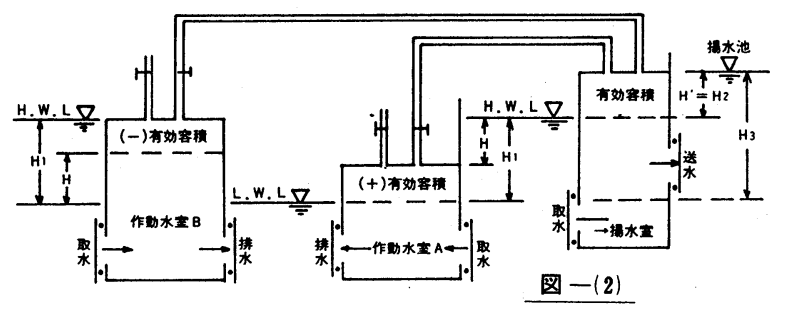


階段状水室は、最初その下部にある揚水室の水門を閉じて作動水室から(十)圧を作用させ、次に送水水門を開い て、H.W.L.より $\mathrm{H}^{\prime}$ 高い揚水室へ送水する。

(2) $\mathrm{D}$ 型

この装置は C 型よりさらにシステムを単純化することにより、大量の流量を処理するものである。図一(3)に示す ように作動水室は(十)圧のみであり、階段状水室は無く、H.W.L.下に設置された揚水室から直接揚水池に送水する。

（行程） 作動水室 $\mathrm{A}(+)$ 圧は、取水水門を開いて自 然流入させるととにより(十)が生ずる。

揚水室は、H.W.L.の高さまで満水にして取水水 門を閉じる。次に作動水室から(十)圧を作用させ、同

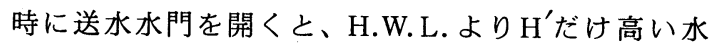
位の揚水池に送水することができる。

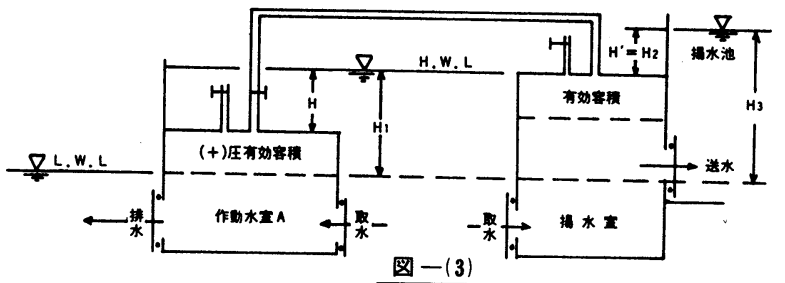

(3) 各型式の精能

$\mathrm{A}$ 型と同じ作動水室を用い る場合の C 型と D 型の精能を 示すと表一(1)のようになる。 これにより両者を比較すると、 単位時間揚水量と揚程は C 型 の方が若干よい。しかしD型 は効率がよく、また使用水量 も少いので、装置の規模が小 さくなるととが有利である。

\section{3 . 潮汐発電への適用}

わが国で潮汐発電の有望な 地点は有明海であり、年占の概 念設計は新発電方式総合調査 委員会により昭和 47 年に報告 された。これによると多比良 一長洲間は図一(4)のように締

\begin{tabular}{|c|c|c|c|c|c|c|c|c|c|}
\hline 型式 & 侀㖶水室 & 傮段状水室 & 存牞水頍 & 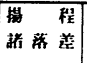 & 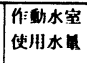 & 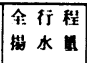 & 所要時間 & 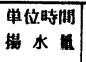 & 刈 \\
\hline A & $\begin{array}{l}\mathrm{A}(\mathrm{H}) \text { 压 } \\
0.7 \mathrm{~m} \times 0.7 \mathrm{~m} \times 0.4 \mathrm{~m} \\
\text { B(HEI } \\
0.7 \mathrm{~m} \times 0.7 \mathrm{~m} \times 0.4 \mathrm{~m}\end{array}$ & $\begin{array}{l}5 \varepsilon^{2} \\
0.4 \mathrm{~m} \times 0.4 \mathrm{~m} \times 0.5 \mathrm{~m}\end{array}$ & 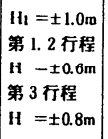 & $\begin{array}{l}\mathrm{H}^{\prime}=0.5 \mathrm{~m} \\
\mathrm{H}_{2}=2.5 \mathrm{~m} \\
\mathrm{H}_{3}=3.5 \mathrm{~m}\end{array}$ & $0.90 \quad \mathrm{trr}$ & $0.08 \mathrm{~m}$ & 70.3 杪 & $0.00113 \mathrm{~m}^{\prime}$ & $22.2 \%$ \\
\hline c & 上 & $\begin{array}{l}1 \text { 段 } \\
0.58 \mathrm{~m} \times 0.58 \mathrm{~m} \times 0.5 \mathrm{~m}\end{array}$ & $\begin{array}{l}\mathrm{H}= \pm 1.0 \mathrm{~m} \\
\mathrm{H}= \pm 0.6 \mathrm{~m}\end{array}$ & $\begin{array}{l}\mathbf{H}^{\prime}=0.5 \mathrm{~m} \\
\mathrm{H}_{2}=0.5 \mathrm{~m} \\
\mathrm{H}_{3}=1.5 \mathrm{~m}\end{array}$ & $0.392 \mathrm{mr}$ & $0.168 \mathrm{mr}^{2}$ & 16 秒 & $0.0105 \mathrm{~m}^{2}$ & $21.4 \%$ \\
\hline D & 上 & な & $\begin{array}{l}\mathrm{H} 1= \pm 1.0 \mathrm{~m} \\
\mathrm{H}= \pm 0.7 \mathrm{~m}\end{array}$ & $\begin{array}{l}\mathrm{H}^{\prime}=0.3 \mathrm{~m} \\
\mathrm{H}_{2}=0.3 \mathrm{~m} \\
\mathrm{H}_{3}=1.3 \mathrm{~m}\end{array}$ & $0.135 \mathrm{~m}$ & $0.115 \mathrm{~m}^{2}$ & 14 秒 & $0.008 \mathrm{~m}^{2}$ & $25.6 \%$ \\
\hline
\end{tabular}

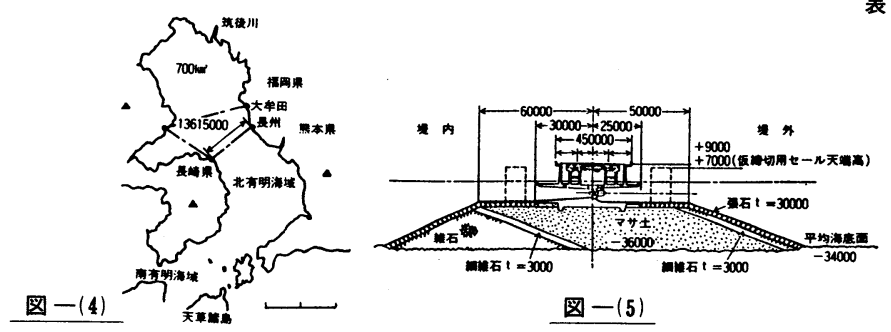

切られ、貯水面積 $700 \mathrm{~km}^{2}$ 、有効貯水量 14 億 $\mathrm{m}^{3}$ が得られる。最大潮差 $4.56 \mathrm{~m}$ 、平均 $3.18 \mathrm{~m}$ で、一池一方向方式に よる場合、満水位より $2 \mathrm{~m}$ 下りまで（ $4.5 \mathrm{~m} \sim 2.5 \mathrm{~m}$ の落差）が発電に利用され、残りはデッドゥォーターにな る。水車はチューブラ型、ランナー径 $5 \mathrm{~m}$ のもの 100 台案と 200 台案が示され、基準有効落差 $4.5 \mathrm{~m}$ で $5,000 \mathrm{~kW}$ である。乙の計画は大規模なものであるため、筆者らの装置をそのまま適用することはむつかしいので、先ず実 験プラントとじて、発電容量を $500 \mathrm{~kW}$ 縮少したD型装置について提案したいと思う。

(1) 揚水装置の設計

概念設計に示された提体は、図ー(5)のようにマゥンド上の天端幅が $110 \mathrm{~m}$ あるので、その上に D型装置を設定 するものとして次の寸法にする。

（作動水室） $\mathrm{A}(+)$ 圧の有効容積 $50 \mathrm{~m} \times 50 \mathrm{~m} \times 1 \mathrm{~m}=2,500 \mathrm{~m}^{3}$, 取水水門,排水水門各 $2,15 \mathrm{~m} \times 1.25 \mathrm{~m}$, 流量係数 0.7 （揚 水 室） 揚水室の有効容積 $40 \mathrm{~m} \times 40 \mathrm{~m} \times 1 \mathrm{~m}=1,600 \mathrm{~m}^{3}$, 取水水門,排水水門各 $2,10 \mathrm{~m} \times 1.25 \mathrm{~m}$, 流量係数 0.7 (発電水車) チューブラ水車, 定格 $500 \mathrm{~kW}$, 使用水量 $15 \mathrm{~m}^{3} / \mathrm{S}$

（運転システム） 1 行程: 揚水室 $\rightarrow$ 揚水池 （準備: 揚水室への自然流入と弁の操作）

（諸值）落差の変化に対応する諸値は表一(2)のよ5になる。

表に示した値は、装置の設置 位置が、夫々の条件に対応する ものとした值であるが、実際に は貯水池の水面と海面が変化す るので、固定された装置では余 分の空間が生ずることになる。 例えば揚水室の上辺が(a)の条件 に合うように固定すれば、(b)と (c)では有効容積の位置が変化す るため、上部に余分の空間を生

\begin{tabular}{|c|c|c|c|c|c|c|c|c|c|}
\hline & 落差の紊換 & 有剂水畐 & 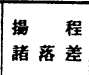 & 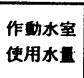 & 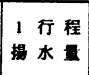 & 所要時间 & 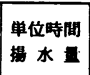 & 奻事 & 発西出力 \\
\hline (a) & 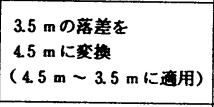 & $\begin{array}{l}\mathrm{H}_{1}=3.5 \mathrm{~m} \\
\mathrm{H}=2.5 \mathrm{~m}\end{array}$ & $\begin{array}{l}H^{\prime}=1.0 \mathrm{~m} \\
H_{2}=1.0 \mathrm{~m} \\
H_{3}=4.5 \mathrm{~m}\end{array}$ & $2,180 \mathrm{mt}^{\prime}$ & $1,600 \mathrm{~m}^{\mathrm{t}}$ & 52 秒 & $15 \mathrm{~m}^{2}$ & $21 \%$ & $\begin{array}{c}\mathrm{P}=9.8 \eta \mathrm{QH} \\
=529 \mathrm{~kJ} \\
(\eta=80 \%)\end{array}$ \\
\hline (b) & 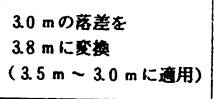 & $\begin{array}{l}\mathrm{H}_{\mathrm{l}}=3.0 \mathrm{~m} \\
\mathrm{H}=2.0 \mathrm{~m}\end{array}$ & $\begin{array}{l}\mathrm{H}^{\prime}=0.8 \mathrm{~m} \\
\mathrm{H}_{2}=0.8 \mathrm{~m} \\
\mathrm{H}_{3}=3.8 \mathrm{~m}\end{array}$ & $2.100 \mathrm{~m}^{\prime}$ & $1,600 \mathrm{~m}^{\mathrm{s}}$ & 51 秒 & $15 \mathrm{~m}^{2}$ & $20.3 \%$ & $\begin{array}{l}P=418 \mathrm{kI} \\
(\eta=75 \%)\end{array}$ \\
\hline (c) & 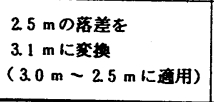 & $\begin{array}{l}\mathrm{H}_{1}=2.5 \mathrm{~m} \\
\mathrm{H}=1.5 \mathrm{~m}\end{array}$ & $\begin{array}{l}\mathrm{H}^{\prime}=0.6 \mathrm{~m} \\
\mathrm{H}_{2}=0.6 \mathrm{~m} \\
\mathrm{H}_{3}=3.1 \mathrm{~m}\end{array}$ & $2.060 \mathrm{mt}$ & $1,600 \mathrm{~m}^{\circ}$ & 51 溇 & $15 \mathrm{~m}^{\circ}$ & $186 \%$ & $\begin{array}{l}P=310 \mathrm{~kJ} \\
(\eta=68 \%)\end{array}$ \\
\hline
\end{tabular}

ずる。また作動水室では、上辺が(c)の条件に合うように固定すれば、(a)と(b)では有効容積の位置が変化するため、 
上部に余分の空間を生ずる。乙の空間のために余分のエネルギーを消耗するので、その対策として、行程開始前 に、隣接するセットの行程終了後の余剩エネルギーを導いて予圧した状態にする方法が考えられる。また運転シ ステムについても、作動水室と揚水室を $1 ： 1$ の対応ではなく、複数箇の対応とし、作動水室前半の行程と揚水 室後半を対応させ、作動水室後半の行程と揚水室前半を対応させる方法などにより、上記による損失を補うよう にする。なおこのようなシステム及び気圧回路の設計などについては、別の機会に報告するつもりである。

(2) 揚水装置適用による効果

揚水装置を適用した場合の発電量を概算する。先ず有明海の調查資料による発電可能な時間帯は表一(3)-(a)に 示される。乙れによって定格 $500 \mathrm{~kW}$ の発電量を計算すると表一(b)のようになる。次に同じ時間帯に揚水装置を設 定した場合の発電量を計算すると表一(c)のようになる。

\begin{tabular}{|c|c|c|c|}
\hline 潮 & 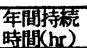 & 回 数 & 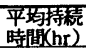 \\
\hline $2.5 \mathrm{~m}$ 以上 & 2,000 & 520 & 3.85 \\
\hline $3.0 \mathrm{~m}$ 以上 & 1,300 & 430 & 3.0 \\
\hline $3.5 \mathrm{~m}$ 以上 & 700 & 330 & 2.1 \\
\hline $4.0 \mathrm{~m}$ 以上 & 300 & 180 & 1.7 \\
\hline
\end{tabular}

\begin{tabular}{|c|c|c|c|c|}
\hline 潮 差 & 登䨞 & 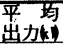 & 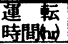 & 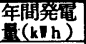 \\
\hline $2.5 \mathrm{~m}$ & 220 & & & $\times 10^{3}$ \\
\hline & & 260 & 700 & 182 \\
\hline & 000 & 330 & 600 & 198 \\
\hline $3.5 \mathrm{~m}$ & 360 & 395 & 400 & 158 \\
\hline 4. $0 \mathrm{~m}$ & 430 & 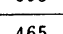 & 330 & 139 \\
\hline 4. $5 \mathrm{~m}$ & 500 & 400 & s00 棓 & $677 \times 10^{3}$ \\
\hline
\end{tabular}

\begin{tabular}{|c|c|c|c|c|}
\hline 落 差 & $\begin{array}{l}\text { 発電 } \\
\text { 出加 }\end{array}$ & 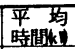 & 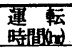 & 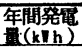 \\
\hline $3.1 \mathrm{~m}$ & 310 & & & $\times 10^{3}$ \\
\hline 29 & 120 & 365 & 700 & 255 \\
\hline & & 460 & 600 & 276 \\
\hline $4.5 \mathrm{~m}$ & 500 & 500 & 400 & 200 \\
\hline $4.5 \mathrm{~m}$ & 500 & 500 & & \\
\hline $4.5 \mathrm{~m}$ & 500 & 500 & 誥 & $\frac{150}{881 \times 10^{3}}$ \\
\hline
\end{tabular}

これによると揚水装置を適用するととによって約 $30 \%$ の発電量の増加になるが、そのうち装置のコントロール などに消費する分を約 $5 \%$ と見込み、実質約 $25 \%$ の増加になると考えている。

(3) 揚水装置の設定

以上の設計による装置をケーソンの中に設定するものとすれば、図一(6)のようになる。この場合、ケーソンの 設計に合わせなければならないので、装置の形態は適宜分割したものにする。水門は空気の混入を防止するため 深所に設置するが、その構造などについては今後の研究としたい。

4. まとめ

本稿では潮汐による

落差を高めるために、

揚水装置 D型を用いる

提案をしたが、結果と

して約 $25 \%$ の発電量の

増加が可能になる。し

かし本装置の構造が偏

平で広い面積を要する

ことから経費面で不利

になるので、その対策

として、提体を構成す

るケーソンを利用するととにしたのである。この工法が可能になれば、揚水装置の主経費は大幅に軽減され、あ とは水門と気圧回路の経費になるので、具体化の可能性が高いと考えている。

本装置の規模は、ケーソンの大きさに制約されるため、出力は小型化するのは止むを得ないので、出力 $500 \mathrm{~kW}$ プラントとしたのであるが、この設計で水門操作の時間を速くする実験に成功すれば、発電量が増加することにな り、また水門を大きくすることができれば出力の増加になるので、実用化をすすめる上で水門の研究は重要である。

潮汐発電の経済性については、来・加両国のファンディ湾における詳細な調査研究があり、実現の段階に達し ていると言われる。またり連では実験用として、キスラヤ・グーバ発電所の出力 $400 \mathrm{~kW}$ 研究成果が注目されて いる。特に建設の主経費となる土木工事には、浮遊工法が大きな成果を得たと言われるので、これらの技術が適 用できるとすれば、筆者らの研究もさらに前進すると思う。

さて 61 年に通産省がまとめた " 21 世紀のエネルギージジョン”によると、石油資源は有限であり、90年代には

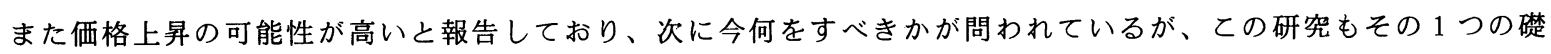
石になるととを期待する。

5. 謝辞

本研究は福井工業大学教授岩井重久先生（京大名誉教授）の特別の御教示と、御指導によって実施されたもの であることを記し、ことに潹甚の謝意を表する次第である。

（参考文献） 1)和田・吉田 : 低落差を高落差に変換する揚水装置と波力発電 : 第40回年次学術講演会第 6 部 2)和田・䇥：落差を利用する揚水装置による発電の研究 : 海洋開発論文集 VOL.2.1986

3)本間 顽也 : 世界における海洋エネルギー利用の動向 : 海洋エネルギーシンポジウム : ECOR 日本委員会 1985.10

4)本間 耗也: 海洋エネルギー読本 P37, P81, P144, P150,オーム社

5)鉿木 晴之: 潮汐発電: オーシャンエージ, 1977, 潮力発電 : エネルギー科学大事典 : 講談社,

潮汐発電 : 海洋工学ハンドブック:コロナ社 